Anni Lappela

\title{
Vuoret ja kaupunki vastakohtaisina tiloina Alisa Ganijevan teoksissa
}

Tässä artikkelissa analysoin vuorten ja kaupungin roolia Alisa Ganijevan teosten tematiikassa geokriittisestä ja postkolonialistisesta näkökulmasta. Keskityn ennen kaikkea hänen romaaniinsa Prazdnitšnaja gora ("Juhlavuori"; tästä eteenpäin PG), mutta sivuan analyysissäni myös hänen pienoisromaaniaan Salam tebe, Dalgat! ("Salaam, Dalgat!"; tästä eteenpäin STB). Lähilukuni tarkoituksena on selvittää, millaisia symbolisia ja metatekstuaalisia merkityksiä vuoret ja kaupunki Ganijevan teoksissa kantavat sekä miten ne osaltaan rakentavat teosten postkolonialistista dystopiaa. Vuoret ovat teoksissa osa sekä "todellista" referentiaalista maailmaa että tekstin sisäistä maailmaa ja sen intertekstuaalisuutta. Pyrin tarkastelemaan sitä, miten vuoret omalta osaltaan konstruoivat tekstin ulkoisen ja tekstin sisäisen maailman välistä suhdetta. Kaupunki on teoksissa ennen kaikkea referentiaalinen ja hahmottuu useilla tavoilla vuorten vastakohdaksi. Tämä vastakohtaisuus on pohja analyysilleni vuorten ja kaupungin rooleista teoksissa.

\section{Geokriittinen näkökulma Ganijevan teoksiin}

Teoreettisena lähtökohtana lähiluvulle on ennen kaikkea geokritiikki, sellaisena kuin Bertrand Westphal ja Robert T. Tally sen ovat muotoilleet, paikoin toisistaan hieman poikkeavin tavoin. Westphal $(2011 \mathrm{a}, 122)$ näkee geokritiikin eri aspektien sisältävän oletuksen referentiaalisuudesta ja katsoo geokritiikin liikkuvan jossakin "reaalisen" ja "kuvitteellisen" maantieteen välimaastossa (Westphal 2011a, 170). Hän siis olettaa fiktiossa kuvattujen paikkojen olevan aina jollain tavalla suhteessa referentiaalisen maailman paikkoihin. Westphal (2011b, xiii) kritisoi strukturalismia toteamalla, että hänen mielestään ”[--] aikakausi, jolloin 'fiktiivinen' kerronta voitiin täysin leikata irti 'todellisesta' maailmasta on päättynyt jo kauan sitten". ${ }^{1}$ Westphalin (2011a, 112-113) mukaan geokriittinen analyysi keskittyy nimenomaan tiettyyn paikkaan eikä yksittäisen kirjailijan tuotantoon, ja geokriittistä luentaa tehdessä huomiota kiinnitetään enemmän tilaan kuin sen yksittäiseen havainnoitsijaan (Westphal 2011a: 131). Geokritiikin tarjoamat analyysivälineet soveltuvat mielestäni kuitenkin myös yksittäisen kirjailijan tuotannon lukemiseen, vaikka tällöin ei pitäydytäkään tiukasti Westphalin geosentrisessä luennassa. Westphal (2011a, 122) määrittelee geokritiikin lähestymistavan neljän keskeisen käsitteen kautta, joita ovat multifokalisaatio, polysensorisuus, kerrostuneisuus (stratigraphy) ja intertekstuaalisuus. Multifokalisaatiolla Westphal (2011a, 129) viit- 
taa toisiaan leikkaavien näkökulmien moninaisuuteen ja siihen, että tekstissä esitetyt näkökulmat tilaan ovat aina riippuvaisia havainnoitsijan suhteesta tilaan (mt., 128). Multifokalisaation ajatus liittyy vahvasti ajatukseen siitä, että geokriittisessä luennassa keskiössä pitäisi olla tietyn tilan, ei niinkään tietyn havainnoitsijan. Polysensorisuudella Westphal (2011a, 131-136) taas tarkoittaa tilan holistista kokemista kaikilla aisteilla, ei vain visuaalisesti. Stratigrafialla Westphal (2011a, 137) viittaa ajan kerroksellisuuteen tekstissä ja esittää, että ajan vaikutus tilan kokemiseen on yksi geokritiikin aspekteista. Etenkin kaksi viimeisintä lähtökohtaa, kerrostuneisuus ja intertekstuaalisuus, ovat tärkeitä luennalleni Ganijevan teksteistä. Esitän, että Ganijevan teosten postkolonialistinen näkökulma tilaan ja vuoriin rakentuu pitkälti teksteissä kuvatun ajan kerrostuneisuuden ja tekstien omintakeisen intertekstuaalisuuden varaan.

Tally $(2011,1)^{2}$ muotoilee geokriitikon tehtävän käsittäen tilan nimenomaan sosiaaliseksi tilaksi: ”[k]irjallista kartografiaa käyttäen kirjailija luo karttoja oman maailmansa sosiaalisista tiloista; geokriitikko voi lukea näitä karttoja kiinnittäen erityistä huomiota kirjallisuuden tilallisiin käytäntöihin”. Ganijevan romaanissa kuvatut tilat ovat korostuneesti nimenomaan sosiaalisia tiloja silloinkin, kun kyse on luonnonpaikoista. Venäläinen ihmismaantieteilijä Dmitri Zamjatin (2010, 127-129) puhuu kuvaannollisesta maantieteestä (imažinalnaja ili obraznaja geografija) ja maantieteellisestä kuvasta (geografitšeski obraz) näitä käsitteitä avaavassa artikkelissaan. Hänen määritelmänsä maantieteellisestä kuvasta ${ }^{3}$ tulee lähelle sitä, miten vuoria Ganijevan teoksissa käsittelen. Ymmärrän vuoret siis romaanin keskeiseksi maantieteelliseksi kuvaksi, joka on erilaisten toisiinsa liittyvien ja yhdessä toimivien merkkien, symbolien, arkkityyppien ja stereotyyppien systeemi.

\section{Ganijevan Dagestaniin sijoittuva tuotanto}

Alisa Ganijeva on julkaissut vasta yhden pienoisromaanin ja kaksi romaania, mutta hänestä on Venäjällä lyhyessä ajassa tullut yksi 2000-luvun kiinnostavimmista ja seuratuimmista kirjailijoista. Ganijeva syntyi Moskovassa vuonna 1985, mutta pian hänen syntymänsä jälkeen perhe muutti Pohjois-Kaukasiaan Dagestaniin, josta hänen vanhempansa ovat kotoisin. Ganijeva kävi koulunsa Dagestanin pääkaupungissa Mahatškalassa ja koulun päätettyään muutti Moskovaan, missä asuu yhä. Hän on opiskellut Moskovan maineikkaassa Gorkin kirjallisuusinstituutissa.

Vuonna 2010 julkaistusta esikoisteoksestaan, pienoisromaanista Salam tebe, Dalgat! Ganijeva sai Debjut-kirjallisuuspalkinnon, joka on Venäjän tärkein esikoiskirjailijoille jaettava palkinto. Hän jätti teoksen kilpailuun miessalanimellä ja vasta palkintojenjakoseremoniassa paljastui, että Gulla Hiratšev -niminen mies olikin Alisa Ganijeva -niminen nainen. Pienen performanssin tarkoitusta on arvailtu, ja kenties oikeimpaan osuvat pohdinnat siitä, että Ganijeva halusi leikitellä ennakkoluuloilla, joita Venäjällä 
on kaukasialaistaustaisia kohtaan. Ganijeva julkaisi toisen romaaninsa Prazdnitšnaja gora ("Juhlavuori") vuonna 2012, ja se on julkaistu myös englanniksi vuonna 2015 nimellä The Mountain and the Wall. Kolmannen teoksensa Ženih i nevesta ("Sulhanen ja morsian”) Ganijeva julkaisi vuonna 2015. Kaikki teokset sijoittuvat 2000-luvun Dagestaniin, osin Mahatškalaan ja osin maaseudun kyliin.

Romaanissa Prazdnitšnaja gora Ganijeva kuvaa dystopian kaltaista tilannetta, jossa Venäjä päättää erottaa Dagestanin tasavallan yhteydestään rakentamalla tasavallan rajalle muurin. Dagestan on yksi nykyisen Venäjän tasavalloista ja sijaitsee Kaspianmeren rannalla Etelä-Venäjän Kaukasiassa, Kaukasus-vuoriston pohjoispuolella. Dagestanin itsenäistyminen kuvataan romaanissa kaoottiseksi tilanteeksi, jossa erilaiset poliittiset puolueet, ryhmittymät, ääriliikkeet ja onnenonkijat kamppailevat vallasta itsenäistyvässä nuoressa valtiossa. Radikaalit islamistit perustavat lopulta Kaukasian Emiraatin iskulauseenaan "Meillä ei ole kansoja, meillä on Allah!”’ (PG, 90). Romaanin päähenkilö, nuori toimittaja Šamil, tarkkailee tapahtumia pääasiassa pääkaupungissa Mahatškalassa. Šamil on mahdollisesti saanut nimensä imaami Šamilin (1797-1871) mukaan. Hän oli pohjoiskaukasialainen uskonnollinen ja poliittinen johtaja, joka johti Venäjän vastaista Kaukasian sotaa. Päähenkilö Šamil taas pidättäytyy osallistumasta poliittiseen liikehdintään ja säilyttää läpi romaanin jonkinlaisen tarkkailijan roolin.

Kuten sekä alkuteoksen nimi että englanninnos ilmaisevat, vuorilla on teoksessa keskeinen merkityksiä tuottava rooli. Päähenkilön suhdetta vuoriin kuvataan romaanissa moneen otteeseen.

\section{Venäläinen uusi realismi ja Ganijeva}

Ganijevan romaanit eivät tulkintani mukaan varsinaisesti edusta venäläistä 2000-luvun niin kutsuttua uutta realismia, eikä häntä koskaan kirjallisuuskritiikissäkään siihen liitetä, mutta yhteiskuntakriittisellä teemallaan ja tyylillään ne tulevat lähelle kyseistä suuntausta. 2000-luvulla uudeksi realismiksi on alettu venäläisessä kirjallisuudessa kutsua yhteiskuntakriittisesti suuntautunutta proosaa, joka vaatii kirjallisuudelta ympäröivän todellisuuden valokuvantarkkaa dokumentoimista. Realistinen kirjallisuus on alettu nähdä yhteiskunnallisen keskustelun välineenä, minkä vuoksi sille asetettuun dokumentaarisuuden vaatimukseen yhdistyy keskeisellä tavalla korostunut nykyhetkisyys (Klapuri \& Lappela 2015, 94). Kristina Rotkirch luonnehtii venäläistä uutta realismia kirjoittaessaan keskeisimmän uusrealistikirjailijan ja uuden realismin teoreetikkona tunnetun Roman Sentšinin tuotannosta:

Venäläiset uudet realistit ovat nyt kolme-nelikymppisiä, eli he ovat varttuneet perestroikan vuosien ja villin kapitalismin nousun aikana. Siksi heillä ei ole vertailukohdetta, he eivät voi sen enempää kirota kuin kaunistellakaan neuvostoaikaa. Sen sijaan he näkevät tarkkaan heitä ympäröivän todellisuuden. (Rotkirch 2012, 2011.) 
Uusista realisteista puhuttaessa tarkoitetaan siis yleensä lähinnä 1970-luvulla syntyneiden kirjailijoiden joukkoa, johon Ganijeva ikänsä puolesta on hieman nuori. Suhde Neuvostoliittoon esittäytyy hänen tuotannossaan kuitenkin samalla tavalla kompleksisena kuin monilla uusilla realisteilla. Ganijeva viittaa neuvostomenneisyyteen ennen kaikkea interteksteillään, ei konkreettisten tapahtumien tai muistojen kautta. Suhde neuvostomenneisyyteen tulee esiin myös tässä artikkelissa tarkastelemieni kysymysten yhteydessä. Uusien realistien tavoin Ganijeva pysyttelee nykyajassa, josta hänellä on omakohtaista kokemusta.

Uusi realismi on määrittynyt paitsi suhteessa yhteiskunnalliseen muutokseen, myös suhteessa (venäläiseen) postmodernismiin (Klapuri \& Lappela 2015, 93), ja Ganijevakin (2010a, 289) kirjoittaa esseessään venäläisestä uudesta realismista sen olevan ennen kaikkea ohjelmallista postmodernismin vastustamista. Ganijeva (2010a, 293, 316) kirjoittaa uudesta realismista paikoin kriittiseen sävyyn ${ }^{5}$ ja näkee uusia realisteja yhdistävänä tekijänä tietynlaisen mielialan ja (pääasiassa modernistisen ja pessimistisen) maailmankatsomuksen. Kiinnostavaa on, että kirjoittaessaan kirjallisuuden kriisistä Ganijeva (2010b, 288) toteaa itsekin: "[j]otta kirjallisuus tervehtyisi, täytyy ensin parantaa yhteiskunta". ${ }^{6}$ Tällaisella toteamuksella Ganijeva tuntuu argumentoivan kirjallisuuden ja yhteiskunnan suhteesta hyvin samalla tavoin kuin uudet realistit. Myös tässä mielessä fiktion kuvaaman todellisuuden referentiaalisuutta korostava geokritiikki soveltuu niin Ganijevan kuin venäläisten uusien realistien teosten lukemiseen mielestäni hyvin.

Mielestäni Ganijevan erottaa uusista realisteista ennen kaikkea hänen postkolonialistinen näkökulmansa. Siinä missä useimmat venäläiset uudet realistit, kuten Roman Sentšin, Zahar Prilepin ja Sergei Šargunov, keskittyvät pohtimaan nyky-Venäjän yhteiskunnan ja poliittisen kentän tilaa kolme-nelikymppisten venäläisten miesten näkökulmasta, Ganijeva nostaa päähenkilöiksi Dagestanin nuoret aikuiset, jotka etsivät identiteettiään yhtä aikaa venäläisinä ja dagestanilaisina, osana sellaista monikulttuurista Venäjä, josta uusien realistien teoksissa on nähdäkseni vain harvoja viitteitä. Ylipäätään postkolonialistisia sävyjä on venäläisessä uudessa kirjallisuudessa mielestäni verrattain vähän, ja postkolonialistisesta näkökulmasta uutta venäläistä kirjallisuutta on myös tutkittu vielä hyvin vähän.

Ganijevan tuotannon suhde Kaukasian kuvaamisen traditioon venäläisessä kirjallisuudessa on monimutkainen kysymys, jonka tutkiminen vaatisi oman artikkelinsa. Toivon voivani kirjoittaa siitä perusteellisemmin toisaalla, mutta tässäkin artikkelissa sivuan aihetta sikäli kun se liittyy varsinaisiin tutkimuskysymyksiini vuorten roolista ja tilasta Ganijevan tuotannossa. Postkolonialistisen kirjallisuuden tilan tutkiminen geokriittisestä näkökulmasta asettaa mielestäni erityisesti kysymyksiä ajan kerroksellisuudesta tekstin kuvaamissa tiloissa. Westphal $(2011,61)$ toteaa postkolonialististen tekstien tutkimista pohtiessaan, että ongelma ei ole niinkään referentin ja sen representaation tutkimisessa, vaan kahden selkeästi diakronisen tilan, kolonialistisen ja 
postkolonialistisen, päällekkäisyydessä. Näiden tilojen päällekkäisyys ja lomittuminen ovat tyypillisiä Ganijevan teksteille, ja esitän, että tämä päällekkäisyys on korostuneen metatekstuaalista.

1800-luvulla Venäjän imperiumin rakentajat, jotka olivat hyvin perehtyneet läntiseen orientalismiin ja eurooppalaiseen imperialismiin Aasiassa, ottivat vaivatta Kaukasian haltuunsa "omana" orienttinaan (Layton 1994, 1). Kaukasuksen kuvaamista 1800-luvun venäläisessä kirjallisuudessa tutkinut Susan Layton (1994, 288) tiivistääkin, että hänen nähdäkseen kirjallinen Kaukasia oli pitkälti venäläisten miesten projekti ja palveli heidän psykologisia tarpeitaan. Tätä Kaukasuksen kuvaamisen miehistä kaanonia Ganijevan proosa uudistaa ja paikoin ironisoi monin tavoin.

Ganijeva sijoitetaan kirjallisuuskritiikissä venäläisen nykykirjallisuuden kentälle hänen kaukasialaisten juuriensa ja vähemmistöjen identiteettiä käsittelevän tematiikkansa kautta. Ganijeva tuntuu mielellään ottavan roolin sukupolvensa kaukasialaisten nuorten aikuisten äänenä. Tästä kertoo mielestäni osaltaan se, että Ganijeva on koonnut ja toimittanut vuonna 2008 julkaistun Molodaja kavkazkaja literatura -antologian ("Nuori kaukasialainen kirjallisuus"), joka tietääkseni on ensimmäinen Venäjällä julkaistu antologia kaukasialaisten uuden polven kirjailijoiden tekstejä. Teokseen esipuheen laatinut Sergei Filatov $(2008,3)$ aloittaa viittaamalla 1990-luvulta lähtien Kaukasiassa jatkuneisiin levottomuuksiin ja haastaa kirjailijoita kysymällä: "[k]aikki nämä vuodet minua on vaivannut yksi kysymys - miksi älymystö on vaiennut nämä raskaat vuodet, miksi poliitikot ja sotilaat ovat ottaneet harteilleen ratkaisut kaikkiin ongelmiin?”. ${ }^{7}$ Kysymys on ollut antologian kokoamisen alkusysäyksenä, ja samalla se tulee lähelle kirjallisuuden uuden realismin ydintä, kysymystä siitä, mikä on kirjallisuuden yhteiskunnallinen rooli ja vastuu nyky-Venäjällä. Sekä Filatov että Ganijeva toteavat esipuheissaan, ettei kaukasialainen kirjallisuus elä parhaita vuosiaan juuri nyt. Kumpikaan heistä ei varsinaisesti käsittele maantieteellisesti muualla kirjoitettua Kaukasiaa käsittelevää proosaa, jota moskovalaisen Ganijevan omakin tuotanto edustaa. Ganijevan esipuheessa kiinnostavaa on se, että siinäkin yhteiskunnalliset kysymykset tulevan ennen kirjallisuuden kysymyksiä. Hän luettelee uuden polven kirjailijoita vaivaavia kysymyksiä seuraavassa järjestyksessä: geopoliittinen epästabiilius, kirjallisuuden taantuma ja kulttuurin kehittymisen kriisiytyminen (Ganijeva 2008, 6).

Ganijevan suhde sekä uuteen realismiin että kaukasialaiseen nykykirjallisuuteen on taustaa sille, miten erottamaton osa yhteiskunnalliset kysymykset ja Dagestanin pitkään jatkuneet levottomuudet ovat hänen teostensa tematiikkaa ja syntyhistoriaa.

\section{Vuoret ja kaupunki osana utopia- ja dystopiadiskurssia}

Ihmismaantieteilijä Yi-Fu Tuan analysoi teoksessaan Romantic Geography. In Search of the Sublime Landscape vuorten merkitystä ja roolia inhimillisessä historiassa ja kulttuurissa. Koska vuoria on pidetty hengellisinä ja pyhinä paikkoina, jumalten asuinsijoina, 
niille on rakennettu pyhäköitä ja temppeleitä vuosisadasta toiseen (Tuan 2013, 42-43). Toisaalta vuoria on pidetty myös hyvin profaaneina paikkoina, joissa lainsuojattomat ja rikolliset ovat piileksineet (mt., 45). Vuoriin liittyvien uskomusten ja metaforien ristiriitaisuus ja vastakohtaisuus tulevat monella tavoin esiin myös Ganijevan teoksissa. Vuoriin liittyy myös paljon sukupuolittavia metaforia, joita pyrin tässä artikkelissa tarkastelemaan osana muita kysymyksenasetteluja. Kaukasian alueita on klassisen venäläisen kirjallisuuden kaanonissa usein feminisoitu ja erotisoitu (ks. Layton 1994), ja tätä kolonialistista kuvaamisen tapaa Ganijeva mielestäni paikoin ironisoi tai vähintäänkin viittaa siihen tietoisesti omassa tekstissään. Otto Boele $(1996,121)$ esittää tutkimuksessaan pohjoisen roolista venäläisessä kirjallisuudessa, että Venäjän etelä mallinnetaan vertikaalisen linjan avulla ja pohjoinen taas horisontaalin kautta. Boele käyttää useita Kaukasiaan sijoittuvia tekstejä esimerkkeinä vertikaalisesta tilasta kirjallisuudessa. Pohjoisen ja etelän naishahmoja venäläisessä kirjallisuudessa tutkiessaan Boele (1996, 196) tekee varsin samankaltaisia johtopäätöksiä kirjallisuudessa esitetyistä stereotyyppisistä etelän naishahmoista kuin Layton.

Ganijevan romaanissa Prazdnitšnaja gora kylä ylhäällä vuorilla ja Mahatškalan kaupunki alhaalla Kaspianmeren rannalla ovat toisilleen monin tavoin vastakohtaisia tiloja ja miljöitä. Tämän vastakohtaisuuden tarkastelu on artikkelini lähtökohta.

Matala-korkea-vastakohtapari, josta Tuan kirjoittaa vuorten kulttuurisia merkityksiä analysoidessaan, on Ganijevan romaanissa siis läsnä. Tähän vastakohtapariin liittyy keskeisesti myös Ganijevan romaanissa toistuva heräämisen ja nukahtamisen kuvaaminen. Uni ja valve hahmottuvat romaanissa osaksi tiettyjä tiloja, joista tämän seurauksena tulee unen ja valveen tiloja. Tuanin analyysissä "matala" yhdistyy usein profaaniin ja materiaaliseen ja "korkea" taas ylevään, henkiseen ja poikkeukselliseen. Tuan (2013, 46) huomioi kuitenkin myös assosiaatiot, joissa matala yhdistyy elinvoimaisuuteen ja terveyteen ja korkea taas dekadentiksi kääntyvään sofistikoituneisuuteen.

Ganijevan romaanissa kylä vuorilla edustaa henkistä ja poikkeuksellista paikkaa, mitä jo kylän, ja samalla Ganijevan romaanin, nimi korostaa: Rohel-Meer, Juhlavuori. Mahatškalan kaupunki rannalla taas yhdistyy romaanissa toistuvasti arkipäiväiseen elämään ja materiaalisiin arvoihin: "Aamulla kaupunki heräsi eloon uudistunein voimin. Työmiehet kiirehtivät kuoppaisia teitä pitkin pölyisissä työhaalareissaan [--]. Šamil heräsi krapulaan [--].” (PG, 55.) ${ }^{8}$ Arkisuudessaan kaupunki asettuu selkeästi vuorten vastakohdaksi. Siellä kaikki on tavallista ja toistuvaa, kun taas vuorilla kaikki on juhlaa, poikkeuksellista ja ainutkertaista. Romaanin loppuratkaisu, jota käsittelen myöhemmin, alempana käsitelty unijakso sekä romaanissa kuvatun vuoristokylän nimi Rohel-Meer, Juhlavuori, ovat selkeimpiä viittauksia tähän vuorten rooliin juhlien ja muiden poikkeuksellisten tapahtumien miljöönä.

Ganijevan kuvaukseen kylästä ja kaupungista tiloina yhdistyy vahvasti myös ajallisuus. Kylä assosioituu selkeästi menneisyyteen ja "perinteiseen” elämäntapaan, kaupunki 
taas nykyhetkeen, moderniin ja tulevaisuuteen. Romaanin nykyhetken aika hahmottuu seurauksena tästä nimenomaan tilan kautta: nykyhetki on liikettä menneisyyteen assosioituvan vuoristokylän ja tulevaisuuteen assosioituvan kaupungin välillä.

Vuoret ja vuoristokylä assosioituvat romaanissa vahvasti uneen. Päähenkilö Šamil muistelee patikkaretkeä, jonka hän joitakin vuosia sitten teki ystävänsä Aripin kanssa ylös vuorille. He päätyivät pieneen Juhlavuori-nimiseen kylään omituisen, sananlaskuilla puhuvan vanhan miehen vieraiksi. Vierailun jälkeisenä aamuna he heräävät kuitenkin samasta paikasta vuorenrinteeltä, johon illalla muistavat käyneensä nukkumaan: "Herätessään hän näki makaavansa surisevalla, aurinkoisella vuorenrinteellä, samassa paikassa, mihin oli Aripin kanssa nukahtanut, reitillä kylään. - Oliko illallinenkin vain unta? Šamil ihmetteli.” (PG, 47.) $)^{9}$ Muistellessaan tapahtunutta jälkeenpäin, romaanin nykyhetkessä, Šamil pohtii samoin: "Vielä enemmän kuin silloin, se tuntui hänestä unelta" (PG, 47). ${ }^{10}$ Lukija on päähenkilön kanssa saman tulkinnallisen ambivalenssin edessä: sen, onko kylä unta vai totta, kirjailija jättää tarkoituksella epäselväksi.

Kylän olemassaolon tulkinnallisuus korostaa mielestäni myös Ganijevan romaanista harvemmin esiin nostettua puolta, eli utopiaa osana sen tematiikkaa. Kirjallisuuskritiikissä Ganijevan romaania kuvataan usein antiutopiaksi tai dystopiaksi, mitä se onkin, mikäli tulkitsemme dystopioiksi teokset, joissa valtio on keskeinen toimija. Valtion rooli keskeisenä toimijana on dystopialle ja antiutopialla tyypillisenä pidetty piirre (esim. Ågren 2014, 12). Kuten Erika Gottlieb $(2001,8)$ toteaa, jokainen dystooppinen yhteiskunta pitää sisällään myös utopistisen unelman siemeniä. Tällainen asetelma löytyy myös Ganijevan romaanista, jossa dagestanilaiset haluavat luoda uudesta, itsenäisestä Dagestanista utopistisen unelmavaltion, mutta eivät pääse sopuun siitä, kenen unelma toteutetaan, ja saavat aikaan vain kaaosta, levottomuuksia ja sisällissotaa muistuttavan tilanteen. Lopputuloksena on dystooppinen autoritaarinen valtio, josta päähenkilö pakenee rakastettunsa kanssa vuorille.

Vuoret ja kaupunki ovat romaanissa monella tasolla toistensa vastakohtia, mutta juuri romaanin lopetus avaa mahdollisuuden tulkita vuoret jonkinlaiseksi utopiaksi ja kaupunki dystopiaksi. Vuoristokylä on utopiaa ennen kaikkea kreikan sanan "ou-topos", "ei olemassa oleva paikka", merkityksessä, ei niinkään merkityksessä "eu-topos", "hyvä paikka”. Vuoristokylä kuuluu unen todellisuuteen eikä välttämättä ole siis lainkaan olemassa valvetodellisuudessa. Kaupunki hahmottuu sen dystooppisena vastakohtana valvetodellisuudessa.

Ganijevan romaanin utopia- ja dystopiadiskurssi rakentaa merkittävällä tavalla sen postkolonialistista näkökulmaa. Utopian diskurssi on erityisen relevanttia tutkittaessa sitä, miten postkolonialistiset kirjailijat tulkitsevat kaupunkitilaa (Upstone 2016, 85). Postkolonialistisen romaanin tilaa tutkinut Sara Upstone esittää utopian ja kaupungin kaunokirjallisen kuvauksen yhteydestä seuraavaa: 
Vaikka postkolonialistiset representaatiot korostavat monia utooppisten kaupunkien aineksia, pohjimmiltaan ne eivät suostu leimautumaan utopioiksi. Sen sijaan ne valaisevat urbaanin erittäin subjektiivista luonnetta: sitä, että yhden henkilön utopia on toisen dystopia. Kaupungin torjumisen sijaan kyseessä on pikemminkin ehdotus radikaalisti visioida uudelleen, kyseenalaistaa oletus siitä, että olisi mahdollista rakentaa ideaali, objektiivinen tila, joka kykenisi palvelemaan erilaisia asukkaita. (Upstone 2016, 92-93.) ${ }^{11}$

Upstonen teoriassa jälkitilasta (post-space) keskeistä on ajatus siitä, että kolonialistista utopistista tilaa seuraa kaaos ja tilan uudelleen visioiminen ja uudelleen järjestäminen. Hän esittää postkolonialististen kirjailijoiden luovan tilaa, joka on "mahdollisuuden ja resistanssin aluetta" (Upstone 2016, 11) ${ }^{12}$. Upstone $(2016,12)^{13}$ käyttää sanaa kaaos kuvailemaan "tilan postkolonialistista uudelleen kuvittelemista", siis ei-negatiivisessa mielessä. Upstone $(2016$, 6) käyttää teoksessaan myös termiä "päällekirjoittaminen" (overwriting), jolla hän kuvaa sitä, miten kolonisoitu alue on teksti, jossa alkuperäinen kirjoitus pyyhitään pois ja korvataan uudella representaatiolla. Tällöin uudesta todellisuudesta tulee kerros vanhan päälle (mt.). Tämä todellisuuksien kerroksellisuus, jollaisesta myös Westphal puhuu postkolonialistisen tilan yhteydessä, ilmenee mielestäni hyvin Ganijevan romaanissa, jossa jälkineuvostoliittolaisen todellisuuden monikulttuurisuus nostaa esiin kysymyksiä siitä, missä ovat dagestanilaisen kulttuurin juuret ja onko mitään yhtenäisiä juuria ollut koskaan olemassakaan.

Nämä kysymykset konkretisoituvat Ganijevan kuvatessa kaupunkia sosiaalisena tilana, jossa erilaiset etniset ryhmät kamppailevat vallasta keskenään. Tätä kuvataan Šamilin kävellessä pitkin kaupunkia kuuntelemassa, miten eri kansallisuuksien, kuten kumykkien, lezgien, darginien ja nogaiden, edustajat vaativat suurempaa päätösvaltaa tasavallan johdossa ja huutavat iskulauseitaan:

Olemme kuulleet huhuja, että he aikovat perustaa uuden hallituksen. Miten? Miksi? Nuo hakimit (johtajat, arab.) ovat sulkeutuneet hallitukseen ja päättäneet, että kumykit ovat rauhallisia, kumykit kestävät mitä vain, heidät voi poistaa hallituksesta... (PG, 23) ${ }^{14}$, Eläköön Kumykstanin tasavalta! (PG, $23)^{15}$, Se on kaikki Azerbaidžanin ja Dagestanin vallanpitäjien petollista politiikkaa! (--) Miksi lezgikysymyksestä vaietaan? (--) He aikovat tuhota eteläiset lezgit, mutta se ei tule onnistumaan! (PG, 30) ${ }^{16}$, Yhdistynyt Lezgistan! Yhdistynyt Lezgistan! (PG, 32) ${ }^{17}$.

Tässä kamppailussa yhden ryhmittymän unelma tuntuu olevan toisen ryhmittymän dystopia. Edellä kuvatuissa eri kansallisuuksien vaatimuksissa saada enemmän itsenäistä päätösvaltaa toiset ryhmittymät nähdään pääasiassa uhkana omalle asialle. Kaupunkitilan uudelleen kuvitteleminen johtaa romaanissa umpikujaan, johon asukkaat eivät keksi ratkaisua. Sen sijaan alkavat taistelut ja kaupunki alkaa vähitellen autioitua asukkaiden paetessa sieltä. Kiinnostavaa on se, että myös Salam tebe, Dalgat! -romaanin lopussa referentiaalinen Mahatškalan kaupunki kuvataan autiona tilana, kun päähenkilö kävelee sen öisiä, tyhjenneitä katuja. Kummankin teoksen lopussa kaupunki kuvataan 
siis tyhjäksi tilaksi, johon teosten päähenkilöt reagoivat hyvin eri tavoin: Šamil jättää kaupungin taakseen, kun taas Dalgat istuutuu Lenin-patsaan jalkojen juureen kaupungin keskusaukiolle, aivan kaupungin sydämeen.

\section{Menneisyys ja tulevaisuus osana erilaisia tiloja}

Prazdnitšnaja gorassa Šamil pohtii vaellusretken alussa Dagestanin kulttuurien juuria vuorilla: "Keitä he olivat, nuo ihmiset, jotka asettuivat vuorille kymmenen, sata, viisisataa tuhatta vuotta sitten? Ketkä olivat asuneet Velikentin joenrantakylässä [--]?” (PG, 45.) ${ }^{18}$ Pohdintaa edeltää geokriittisestä näkökulmasta kiinnostava kappale, jossa Šamil miettii historiaa ihmisen ajan mittakaavan sijasta geologisen ajan mittakaavassa:

Ikivihreät rhododendronit kuiskivat tarinaa Kaukasian saaren subtrooppisesta menneisyydestä, kun muinainen meri oli ympäröinyt sitä joka puolelta, maanpinnan kohoamisesta ja ilmaston yhtäkkisestä muutoksesta, vuorten majesteettisesta synnystä, pikkuruisista kansoista, jotka olivat suojautuneet niitten poimuihin ja jotka olivat muistoesineitä ja endeemisiä lajeja, kuten niitä ympäröivä kasvillisuuskin (PG, 45). ${ }^{19}$

Näissä pohdinnoissa vuoret hahmottuvat päähenkilölle paikkana, jota ei voi ajatella ihmisen ajan mittakaavassa. Šamil pohtii omia juuriaan vuorten kautta: hän hahmottaa vuoret kaikkien dagestanilaisten alkukodiksi ja heitä yhdistäväksi tekijäksi. Tässä mielessä romaanin lopetus, jossa Šamil menee vuorilla naimisiin rakastettunsa Asjan kanssa, viittaa myös vahvasti sellaiseen ajatukseen, että kadotettu yhteys ihmisten välillä on löydettävissä nimenomaan vuorilta. Lopetuksen sijoittaminen vuorille kertoo mielestäni ennen kaikkea siitä, että Ganijevan romaani on luettavissa kriittisenä dystopiana, johon jää toivo paremmasta ja utopian mahdollisuus. Tom Moylan ja Raffaella Baccolini $(2003,7)$ ovat klassisen ja kriittisen dystopian eroja analysoidessaan esittäneet, että kriittisten dystopioiden avoin lopetus sisällyttää niihin utopian impulssin. Ganijevan avoimeksi jäää, vuorille sijoitettu lopetus, joka ei kerro, millaiseksi Dagestanin yhteiskunta valtakamppailun jälkeen muodostuu, jättää mahdollisuuden toivolle paremmasta tulevaisuudesta.

Vuorten kuvaaminen feminiinisinä hieman myöhemmin saman retken aikana tuntuu olevan Šamilin fokalisaatiota: "[h] orisontti katosi vuorten puolikaaren taakse toistaen niitten naisellisia muotoja” (PG, 45). ${ }^{20}$ Tämä vuorten kuvaaminen naisellisina viittaa mielestäni edellisen kuvauksen tavoin vuoriin kaikkien kansallisuuksien alkukotina ja äitinä. Vuoret assosioituvat siis Šamilin mielikuvissa vahvasti menneisyyteen ja historiaan.

Vuoret ovat miljöö myös neuvostoaikaan sijoittuvassa romaanissa, josta päähenkilö lukee pätkiä. Romaani on nimeltään 'Rož ne rastet na kamne", "Ruis ei kasva kivessä”, ja se on sosialistisen realismin tuote, jossa kuvataan, miten vuoristokylän ihmiset omaksuvat neuvostoideologian. Samalla se on vuoristolaistytön Maržanan ja 
köyhän työläismiehen Muhtarin rakkaustarina. Ganijeva on sijoittanut romaanista monen sivun mittaisia lainauksia omaan tekstiinsä. Näen näillä pitkillä sitaateilla kolme funktiota Ganijevan romaanissa. Ennen kaikkea ne tuovat neuvostohistorian läsnä olevaksi 2000-luvulle sijoittuvaan romaaniin. Neuvostomenneisyyteen ei romaanissa muuten juuri viitata, mutta siteerattu romaani tuo sen osaksi nykyhetkeä. Lisäksi sitaatit ovat metakommentointia, joka tuntuu asettavan kysymyksiä kirjallisuuden roolista yhteiskunnassa. Ganijevan dystooppinen romaani on selkeästi yhteiskunnallinen, ja sosialistista realismia edustavasta teoksesta poimitut sitaatit osana sen kerrontaa tuntuvat asettavan kysymyksen siitä, millaista yhteiskuntaa kohti nyt ollaan menossa.

Kyseisessä romaanissa vuoret edustavat menneisyyttä ja traditioita, joista uusi sosialistinen valta vuoristokylän asukkaat vapauttaa. Romaanikatkelmissa viitataan vuoriin toistuvasti menneisyyteen juuttuneena paikkana, jossa hallitsevat vanhat uskomukset ja perinteet. Kun Maržanan äiti on lähdössä vuorille rukoilemaan toisten naisten kanssa, Maržana toteaa: ”Isä kulkee ympäriinsä heiluttaen jotakin riepua ilmassa, miehet aikovat viettää koko yön veisaten rukouksia, ja sinä menet vuorille. Tämä ei ole sitä, mitä varten neuvostovalta sinut vapautti!” (PG, 37.) ${ }^{21}$ Pioneerien kokoontumista kuvattaessa kuvataan myös vuoria, jotka ovat viimein ihmisten tavoin vapautuneet menneisyyden ja uskonnon painolastista: ”Heidän käsissään kimalsi sähkövalojen köynnös ja heidän kasvojaan valaisi lapsellinen ilo. Vuoretkin olivat valaistut! Ilman mitään rukouksia tai typeriä ympärivuorokautisia vigilioita.” (PG, 37.)22 Puolueen edustaja Raisa Petrovna taas toteaa Maržanalle säälivänsä nimenomaan vuoristokylien naisia: "[n]äen miten alentuvasti miehet kohtelevat teitä täällä, näen miten vaikeaa teillä vuorten naisilla on" (PG, 39). ${ }^{23}$

Päähenkilö Maržana lähtee romaanin lopussa vuorilta ja aloittaa uuden, vapaan elämän kaupungissa. Tässäkin romaanissa vuoret ja kaupunki kuvataan siis vastakohtaisiksi, mutta liike tapahtuu kuitenkin täysin päinvastoin kuin Ganijevan romaanissa: Maržana aloittaa uuden elämän kaupungissa, kun taas Ganijevan päähenkilöt pakenevat kaupungista vuorille aloittaakseen siellä uuden elämänvaiheen.

Ganijevan romaanissa on myös pitkiä sitaatteja fiktiivisen dagestanilaiskirjailijan Mahmud Tagirovitšin runoelmasta ja romaanista. Handulai-nimisen vuoristonaisen onnettomasta rakkaudesta kertovaa Tagirovitšin romaania Šamil lukee loputtoman pitkässä leipäjonossa. Tagirovitšin romaanissa kerrotaan vuoresta nimeltä Rohel-Meer, Juhlavuori. Tagirovitš kuvaa sen pyhäksi vuoreksi: "Sielumme päätyvät ehdottomasti ylös Rohel-Meerin, Juhlavuoren, huipulle. Ja siellä, Meerillä, on puhtauden paikka, missä ei ole puutetta eikä pulaa. Siellä tulee olemaan mahtava kylä [--].” (PG, 108.) ${ }^{24}$ Fiktiivisen Tagirovitšin kirjoittama, Ganijevan itse keksimä teos on romaanin tärkein interteksti. Tagirovitšin tekstissä tunnutaan kuvailevan juuri se salaperäinen kylä, johon Šamil ja Arip vaellusretkellään, mahdollisesti unessa, päätyivät. 
Tagirovitšin teoksen sitaattien funktio on mielestäni metatekstuaalinen. Fiktiivisen Tagirovitšin teksti on Ganijevan itsensä kirjoittamaa, ja vuorten rooli osana nimenomaan tekstin sisäistä maailmaa korostuu. Epätodellisuus, unenomaisuus ja ei-referentiaalisuus korostuvat tekstissä vuoria määrittävinä tekijöinä. Päähenkilön todellisuus kaupungissa on niille vastakohtainen. Šamilin kaupungille on vastineensa myös tekstin ulkopuolisessa referentiaalisessa todellisuudessa. Vuoret taas pakenevat Ganijevan kerronnassa tavanomaista referentiaalista suhdetta todellisuuteen. Vaikka romaanissa liikutaan myös konkreettisilla vuorilla, vuoret kuvataan ennen kaikkea unen ja utooppisen tulevaisuuden paikkana.

Samaa keinoa tuoda ympäröivä luonto ja vuoret osaksi tekstin intertekstuaalista karttaa Ganijeva käyttää myös pienoisromaanissaan Salam tebe, Dalgat!, jossa päähenkilö Dalgat samalla tavoin pysähtyy hetkeksi lukemaan sattumanvaraisesti valikoitunutta fiktiivisen dagestanilaisen kirjailijan kirjaa. Dalgatin lukemassa kirjassa, jonka nimeä ei mainita, kirjailija kuvaa pateettiseen sävyyn suhdettaan monikansalliseen synnyinseutuunsa ja sen luontoon. Derbentin kaupunkia kuvatessaan kirjailija pohtii sitä nimenomaan sen maantieteellisen sijainnin ja menneisyyden kautta:

Ajattelin sitä, että tämä tasankokaistale, jota kutsutaan Kaspian reitiksi, yhdisti joskus Itä-Euroopan ja Etu-Aasian. Nyt se levittäytyi keltakivisenä kekona, kahtena eri ajoilta peräisin olevana hautausmaana ja keskiaikaisina kortteleina, jotka laidoilla muuttuivat uudeksi, ikäväksi kaupungiksi. (STB, 60. $)^{25}$

Sitaatissa kuvataan olemassaoleva, referentiaalinen Derbentin kaupunki uudeksi ja ikäväksi. Tässäkin referentiaalinen kaupunki näyttäytyy arkisena ja ikävänä vastakohtana historiallisille ja ihmistä suuremmille maastonmuodoille. Kuten Prazdnitšnaja gorassa, myös esikoisteoksessaan Ganijeva hyödyntää kartografista ja geologista kuvastoa. Dalgatin lukemassa kirjassa historian pohtiminen aloitetaan samalla tavoin geologisessa mittakaavassa kuin Šamil sitä Prazdnitšnaja gorassa pohtii. Mielestäni tämä korostaa maantieteellisten paikkojen merkitystä osana ajallisuuden kokemusta Ganijevan teoksissa.

Dalgatin lukemassa kirjassa kuvataan vuorten huippuja nimenomaan henkien unenomaisina asuinsijoina, joihin tavallisen kuolevaisen tulisi suhtautua kunnioittavasti. Ne ovat myös paikkoja, joissa ihminen kokee pelkoa ja vierautta:

Bazardjuzju-Kitšendag, "pelon vuori", levittäydyttyään kahdeksine jäätikköineen säihkyi alapuolellamme ja hengitti kylmyyttä. Šalbuzdagin huipulla, missä ennen asuivat eren-henget, ei kasvanut mitään. Näin vain valkoisten usvien kiehuvan. Hiuksiin ja kulmakarvoihin kasvoi kuuraa ja tärisin pelosta ja kylmästä. $(\mathrm{STB}, 63 .)^{26}$

Kuten Šamil suhtautuu ironisesti lukemaansa neuvostoliittolaiseen romaaniin, myös Dalgat suhtautuu ironisesti lukemaansa kansallisromanttiseen teokseen. Ganijeva kuvaa 
päähenkilöiden reaktioiden kautta uuden sukupolven kompleksista suhdetta historiaan, tai pikemminkin heidän yritystään muodostaa jonkinlainen suhde menneisyyteen.

Prazdnitšnaja gorasta löytyy myös kaksi selkeää kohtaa, joissa vuoret liittyvät menneisyyden sijasta tulevaisuuteen. Toinen tulevaisuuskuvista on dystooppinen, toinen utooppinen. Nämä tulevaisuuden kuvaukset ovat kiinnostavia ennen kaikkea siksi, että niissä kaupunki ja vuoret kuvataan symbioottiseen suhteeseen, jossa toista ei ole ilman toista. Kummassakin puhutaan energian tuotannosta:

Liikkui pelottavia huhuja sabotaaseista vesivoimalaitoksissa vuorilla.

Tširkein vesivoimalaitoksen valtavan padon tuhoaminen ei pelkästään sammuttaisi sähköjä koko Emiraatin alueelta, vaan myös päästäisi Sulakjoen valkoiset vedet syöksymään alas vuoren rinnettä, Kaspian alangoille ja Mahatškalaankin. (PG, 90.) ${ }^{27}$

Tämä kuva kaupungin tuhoutumisesta ei toteudu, mutta sen mahdollisuus tuo romaanin kaupunkikuvaan apokalyptisen vivahteen. Kaupungin tuhoutuminen vedenpaisumuksessa on yksi kaupunkitekstien apokalypsin arkkityyppi. Huomattavaa tässä tuhon visiossa on se, että uhka tulee vuorilta. Vuoret eivät romaanissa hahmotu siis pelkästään utooppisena unen todellisuutena, vaan myös vaaran ja pelon lähteenä. Tällä tavoin Ganijevan romaanin vuoret sisältävät Tuanin vuorimytologialle hahmottamat kaksi vastakohtaista elementtiä: ne ovat sekä pyhä että profaani paikka, sekä turvapaikka että uhka.

Toisessa tulevaisuuden kuvauksessa päähenkilön ystävän Aripin isä visioi tulevaisuutta, jossa Dagestanin tarvitsema energia tuotetaan ekologisin menetelmin: "[--] olemme jo rakentaneet rakennuksen, joka toimii ympäri vuoden luonnon energialla. Pian Kaspian alue ja vuoret ovat täynnä valosähkö-, termodynamiikka-, aurinkobiopolttoaine- ja aurinkotuulivoimaloita...” (PG, 93.) ${ }^{28}$ Vuoret ovat tässä kuvauksessa jälleen utooppinen paikka, jossa tulevaisuutta rakennetaan ekologisesti kestävien, nykyaikaisten periaatteiden mukaan. Nämä kaksi kuvausta vuorista osaltaan rakentavat romaanin avointa lopetusta, joka jättää lukijan pohdittavaksi kysymyksen siitä, millainen tulevaisuus vuorten ja kaupungin asukkaita odottaa.

\section{Lopuksi}

Tarkastelin tässä artikkelissa vuorten ja kaupungin vastakohtaisuutta Alisa Ganijevan romaanissa Prazdnitšnaja gora sekä hänen pienoisromaanissaan Salam tebe, Dalgat!. Vuoret liitetään teoksissa toistuvasti menneisyyteen ja historiaan, mutta lopulta myös tulevaisuuteen. Kaupunki taas liitetään vahvasti romaanissa Prazdnitšnaja gora nykyhetkeen ja poliittiseen kaaokseen. Näen tämä ajan kerroksellisuuden paikkojen kuvaamisessa osana romaanin postkolonialistista diskurssia: Ganijeva kuvaa aikaa ennen neuvostovaltaa, neuvostovallan aikaa, neuvostovallan jälkeistä nykyhetkeä sekä viittaa 
tulevaisuuteen. Näissä kuvauksissa vuoret ovat merkittävässä roolissa ja päähenkilö hahmottaa omaa suhdettaan kotiseutuunsa sekä menneisyyteen ja tulevaisuuteen toistuvasti nimenomaan vuorten kautta. Myös teoksessa Salam tebe, Dalgat! päähenkilö assosioi kaupungin arkiseen nykyhetkeen ja vuoret salaperäiseen menneisyyteen.

Romaanin kuva nykyhetkestä on dystooppinen, mutta en tarkastellut romaania tässä osana venäläisessä nykykirjallisuudessa suosittua dystopia- ja antiutopiakirjallisuutta. Ganijevan tarkasteleminen osana sitä vaatisi oman artikkelinsa. Tarkastelin Ganijevan romaanin dystopiaa ja utopiaa geokriittisestä näkökulmasta analysoiden sitä, millainen rooli vuorilla ja kaupungilla on romaanin utopia- ja dystopiadiskursseissa.

Ganijevan postkolonialistinen dystopia luo sekä kaupungista että vuorista kuvan jälkitiloina (post-space), eräänlaisena kaoottisena tabula rasana, joka päähenkilöiden pitää kuvitella ja hahmottaa uudelleen. Kaupungin kohdalla tämä uudelleen kuvitteleminen jää jokseenkin alkutekijöihinsä, mutta vuoriin liittyvien kuvausten ja juonen avulla Ganijeva mielestäni hahmottelee vuorista tilaa, joka on helpommin kuviteltavissa uudelleen. Tätä korostaa varsin konkreettisesti se, että vuoret kuvataan toistuvasti unen ja kuvitelmien paikaksi, joka pakenee suhdetta referentiaaliseen maailmaan. Toisaalta ne kuvataan kuitenkin myös paikaksi, jolle on helpommin visioitavissa onnellinen tulevaisuus kuin kaupungille. Romaanissa liike suuntautuu kaupungista kohti vuoria, mikä tekee niistä paitsi romaanin keskeisen maantieteellisen kuvan, myös sen jälkitilan, jossa on uuden utopian alku.

\section{Viitteet}

1 ")(--) the era when 'fictitious' narrations can be definitely cut off from the 'real' world is long over" (Westphal 2011b, xiii). Kaikki käännökset englannista ja venäjästä ovat kirjoittajan, A.L. 2 "Using literary cartography, a writer maps the social spaces of his or her world; a geocritic would read these maps, drawing particular attention to the spatial practices involved in literature" (Tally 2011, 1).

3 "Maantieteellinen kuva on toisiinsa liittyvien ja yhdessä toimivien merkkien, symbolien, arkkityyppien ja stereotyyppien systeemi, joka yhtä aikaa kirkkaasti ja samaan aikaan riittävän selkeästi luonnehtii jotakin aluetta (paikkaa, maisemaa, aluetta, maata). Maantieteellinen kuva on imaginaarimaantieteen keskeinen käsite." «Географический образ - система взаимосвязанных и взаимодействующих знаков, символов, архетипов и стереотипов, ярко и в то же время достаточно просто характеризующих какую-либо территорию (место, мандшафт, регион, страну). Географический образ - центральное понятие имажинальной географии.» (Zamjatin 2010, 128.)

${ }^{4}$ «У нас нет наций, у нас есть А^мах!» (PG, 90)

${ }^{5}$ Kirjoittaessaan ”vasemmistoradikaaleista" kirjailijoista Ganijeva (2010c, 258) esittää kriittiseen sävyyn eräiden uusien realistien "haikailevan menetetyn neuvostoparatiisin perään". Lisäksi hän useiden muiden kriitikoiden tavoin kritisoi uuden realismin "uutuutta" ja toteaa, että jokaisen 2000-luvun kirjailijan on helppo löytää "kirjalliset esi-isänsä" (Ganijeva 2010b, 283). 
${ }^{6}$ «Чтобы вылечить Аитературу, нужно прежле вылечить общество» (Ganijeva 2010b, 288).

7 «Все эти годы меня мучиц один вопрос - почему в эти тяжелые годы молчит интеллигенция, почему на свои плечи решение всех проблем взвалили политики и воины?» (Filatov 2008, 3).

8 «Утром город зажил с удвоенной силой. По разбитым дорогам заторопились рабочие в пыльных робах (--). Шамиль проснулся с похмельным чувством (--) (PG, 55.)

9 «Проснувшись, он увидел себя Аежащим на жужжащем солнечном склоне - в том самом месте, гАе их с Арипом сморило на подступах к селу. - Неужели и ужин приснился? - удивился Шамиль.» (PG, 47.)

10 «Больше, чем когда-либо, оно показалось ему сном» (PG, 47).

11 "Thus, whilst emphasising many of the elements of utopian cities, postcolonial representations ultimately refuse the utopian label. Instead, they illuminate the intensely subjective nature of urbanity: that the one person's utopia is another's dystopia. This is not a rejection of the city, but rather suggests a radical re-visioning, questioning the premise that it is possible to construct an ideal, objectified space capable of serving a disparate population." (2016, 92-93.)

12 "a site of possibility and resistance" (Upstone 2016, 11)

13 "the postcolonial reimagining of space" (Upstone 2016, 12)

14 «Эти хакимы $\{У$ правители (араб.). $\}$ закрылись у себя в правительстве и решили: кумыки спокойные, кумыки все терпят, их можно убрать из власти...» (PG, 23).

15 ”Аа зАравствует Кумыкская респубиика!” (PG, 23).

16 «Это все предательская политика азербайджанских и дагестанских властей! (--) -

Почему Аезгинский вопрос замалчивается? (--) Они хотят уничтожить южных мезгин, но не получится!» (PG, 30.)

17 «ЕАиный Аезгистан! ЕАиный Аезгистан!» (PG, 32).

18 «Кем были Аюди, населявшие эти горы десять, сто, пятьсот тысяч Ает назад? Кто обитал в прибрежном Великенте (--)? (PG, 45.)

19 «Кустарники вечнозеленого рододендрона нашептывали о субтропическом прошлом Кавказского острова, окруженного Аревним морем, о возвышении земной поверхности и резкой смене климата, о грандиозном рождении гор, в чьих складках укрылись народы-крохи, такие же реликты и эндемики, как окружающая их флора» (PG, 45). 20 «Горизонт прятался за полукруглыми дугами гор, повторяя женственные изгибы» (PG, 45).

${ }^{21}$ «Папа вон вокруг села с какой-то тряпкой носится, мужчины там всю ночь собираются молитвы шептать, а ты на гору полезла! Не Аля того освобожАала тебя советская власть!» (PG, 37.)

22 «В руках у них - светящаяся гирлянда электрических Аампочек, на Аицах мальчишеское Аикование. Вот и в горах есть свет! Без всяких молитв и глупых круглосуточных блений.» (PG, 37.)

23 «Я вижу, как вас тут унижают мужчины, я вижу, как тяжело горянкам» (PG, 39).

${ }^{24}$ «Наши Ауши обязательно окажутся на вершине Праздничной горы. И там, на Меэре, будет чистое место, где нет нужды и скудости. Там будет большой аул (--).» (PG, 108.)

25 «Я думал о том, что это полоска равнины, которую называют Каспийским проходом, когда-то связыва^а Восточную Европу и Переднюю Азию. Теперь она распростерлась 
желтокаменной кучей, Авумя разновременными кладбищами и средневековыми кварталами, переходящими по краям в новый, скучный город.» (STB, 60.)

26 «Базардюзю-Кичендаг, 'гора боязни', с ее восьмью меАниками, вытянувшись, сияла нам снизу и дышала холодом. А на венце Шалбуздага, где раньше обитали духи-эрены, ничего не росло. Я видел только кипение белых туманов. На волосах и бровях моих осел иней, и я залрожац от страха и стужи.» $(\mathrm{STB}, 63$.

27 «Самые страшные толки ходили о готовящихся диверсиях на горных гиАроэлектростанциях. Подрыв гигантской арочной плотины Чиркейской ГЭС не только обесточил бы весь имарат, но еще и наводнил бы кипящими сулакскими водами и прикаспийскую низменность, и даже Махачкалу.» (PG, 90.)

28 «(--) мы уже построили Аом, который круглый год питается природной энергией. А скоро на Каспии и в горах будут созданы фотоэлектрические, термодинамические, солнечно-биогазовые, солнечно-ветряные станции мощностью...» (PG, 93.)

\section{Kirjallisuus}

\section{Primäärilähteet}

Ganijeva, Alisa 2010. Salam tebe, Dalgat! [=STB]. Moskva: Astrel.

Ganijeva, Alisa 2012. Prazdnitšnaja gora [=PG]. Moskva: Astrel. http://www.litres.ru/ pages/biblio_book/?art=4602549 (21.9.2016).

\section{Sekundäärilähteet}

Baccolini, Raffaella \& Tom Moylan 2003. Introduction. Dystopia and Histories. Raffaella Baccolini \& Tom Moylan (eds.), Dark Horizons. Science Fiction and the Dystopian Imagination. New York, London: Routledge, 1-12.

Boele, Otto 1996. The North in Russian Romantic Literature. Amsterdam, Atlanta: Rodopi.

Filatov, Sergei 2009. Predislovije. Alisa Ganijeva (sost.), Molodaja kavkazakaja literatura. Parallelnyje vzgljady. Moskva: Olimp, 3-4.

Ganijeva, Alisa 2009. Ot sostavitelja. Alisa Ganijeva (sost.), Molodaja kavkazakaja literatura. Parallelnyje vzgljady. Moskva: Olimp, 5-6.

Ganijeva, Alisa 2010a (2006). I skutšno i grustno. O motivah izgoistva i ottšuždenija v sovremennoi proze. Salam tebe, Dalgat!. Moskva: Astrel, 289-316.

Ganijeva Alisa 2010b (2005). Ne lez v peklo vpered batki. Salam tebe, Dalgat!. Moskva: Astrel, 267-288.

Ganijeva, Alisa 2010c. Vtšera ne dogoniš, ot zavtra ne uidjoš. Salam tebe, Dalgat!. Moskva: Astrel, 256-266.

Gottlieb, Erika 2001. Introduction. Dystopian Fiction East and West. Universe of Trial and Terror. Montreal: McGill-Queen's University Press, 3-22.

Klapuri, Tintti \& Anni Lappela 2015. 2000-luvun venäläinen uusi realismi. Avain 1/2015, 93-98. 
Layton, Susan 1994. Russian Literature and Empire. Conquest of the Caucasus from Pushkin to Tolstoy. Cambridge: Cambridge University Press.

Milner, Andrew 2009. Changing the climate: the politics of dystopia. Routledge: Continuum: Journal of Media \& Cultural Studies 23, 6, 827-838.

Rotkirch, Kristina 2012. Roman Sentšin ja uusi realismi. Tomi Huttunen ja Tintti Klapuri (toim.), Kenen aika? Esseitä venäläisestä nykykirjallisuudesta. Helsinki: AvainBTJ, 205-214.

Tally, Robert T., Jr. 2011. Introduction: On Geocriticism. Robert T. Tally Jr. (ed.), Geocritical Explorations. Space, Place and Mapping in Literary and Cultural Studies. New York: Palgrave McMillan, 1-12.

Tuan, Yi-Fu 2013. Romantic Geography. In Search of the Sublime Landscape. Wisconsin \& London: The University of Wisconsin Press.

Upstone, Sara 2016. Spatial Politics of the Postcolonial Novel. Abingdon: Routledge.

Westphal, Bertrand 2011a. Geocriticism. Real and Fictional Spaces. Transl. Robert T. Tally Jr. New York: Palgrave McMillan.

Westphal, Bertrand 2011b. Foreword. Robert T. Tally Jr. (ed.), Geocritical Explorations. Space, Place and Mapping in Literary and Cultural Studies. New York: Palgrave McMillan, ix-xv.

Zamjatin, Dmitri 2010. Gumanitarnaja geografija: predmet izutšenija i osnovnyje napravlenija razvitija. Obštšsestvennyje nauki i sovremennost 2010, №4, 126-138. http:// ecsocman.hse.ru/data/2012/09/24/1251347015/Zamyatin.pdf (3.7.2016).

Ågren, Mattias 2014. Phantoms of a Future Past. A Study of Contemporary Anti-Utopian Novels. Acta Universitatis Stockholmiensis. Stockholm Studies in Russian Literature 43. Stockholm: Stockholm University. 